\title{
Serum anti-P53 antibodies and alpha-fetoprotein in patients with non-B non-C hepatocellular carcinoma
}

\author{
Abdel Raouf Abou El Azm*, Mohamed Yousef², Raafat Salah², Wael Mayah², Salwa Tawfeek ${ }^{3}$, \\ Hussien Ghorabah² and Nagwa Mansour ${ }^{2}$
}

\begin{abstract}
The rate of hepatocellular carcinoma (HCC) is increasing worldwide including Egypt. Non-B non-C HCC was reported in some countries. We aimed to investigate P53 antibodies and alpha-fetoprotein in patients with non-B non-C HCC in our region. In a case series study, included 281 patients with HCC and 20 patients with liver cirrhosis of matched age, sex and social factors were received for management at Tanta University Hospitals. Sera were tested for HCV and HBV markers by ELISA/PCR, alpha-fetoprotein (AFP) level and anti-p53 antibody were evaluated by ELISA. Antinuclear antibody, serum copper and iron were assessed in non-viral HCC. Liver scanning and biopsy were evaluated. Non-B non-C HCC patients were $13.87 \%$ of total. P53 antibody serum level in non-B non-C HCC patients showed insignificant difference ( $p>0.05)$ as compared to viral-associated HCC, while significant as compared to cirrhosis. They had significant decrease in serum AFP level $(p<0.001)$ as compared to viral-associated HCC. Their tumors were mainly solitary, and have smaller-sizes. Sensitivity, specificity, PPV, NPV and accuracy test of anti P53 antibody positive patients were 91.52\%, 84.63\%, 90.34\%, 80.2\% and $74.8 \%$ respectively. It correlates positively with AFP, tumor size and staging, MELD score and Child-Pugh score.

Non-B non-C HCC showed high serum prevalence of anti-p53 as viral-associated HCC suggesting an evidence of high onchogenecity. It appears of much benefit in diagnosis, follow up and differentiation from cirrhosis in presence of low levels of alpha-fetoprotein.
\end{abstract}

Keywords: Hepatocellular carcinoma, Non-B non-C HCC, Hepatitis C, P53 antibodies, Alpha-fetoprotein

\section{Introduction}

There is a heterogeneous distribution of $\mathrm{HCC}$ at regional and international levels due to infectious and/or environmental factors that may contribute to risk (Lehman et al. 2007). Egypt has the highest prevalence of HCV worldwide and has rising rates of HCC (Lehman and Wilson 2009).

The major risk factors include chronic HBV and HCV infections and chemical exposures (Wang et al. 2002, and Ertle et al. 2010). Recently, the proportion of non-B non-C HCC has been increasing in many areas of the world (Ertle et al. 2010). The pattern of HCC and its risk factors is changing (Anwar et al. 2008).

The p53 protein is involved in DNA repair and is an oncoprotective antigen. This gene when damaged, leads

\footnotetext{
* Correspondence: aaboalazm@gmail.com

${ }^{1}$ Faculty of Medicine, Tanta University, Egypt and president of the Egyptian

Society of Liver and Environment, Tanta, Egypt

Full list of author information is available at the end of the article
}

to production of anti-p53 and predisposes to various cancers, including HCC (Di Cesare et al. 2001, and Ndububa et al. 2001).

P53 antibodies are predominantly associated with p53 gene mutations (Soussi 2000) in the sera of patients with various types of cancer (Shimada et al. 2003). It was reported with high titration in viral-associated HCC Egyptian patients (Atta et al. 2008).

Due to the alarming increase in the incidence of HCC, there is a need for recent insights on contribution of emerging risk factors of hepatocellular carcinogenesis (Abdel-Hamid 2009), and provide more effective measures for early diagnosis, monitor progress and intervention.

We aimed to determine prevalence and diagnostic utility of P53 antibodies and alpha fetoprotein in patients with non-B non-C HCC in our region.

\section{Springer}

(c) 2013 Abou El Azm et al.; licensee Springer. This is an Open Access article distributed under the terms of the Creative Commons Attribution License (http://creativecommons.org/licenses/by/2.0), which permits unrestricted use, distribution, and reproduction in any medium, provided the original work is properly cited. 


\section{Patients and methods Patients}

In a case series retrospective study, included 281 patients with $\mathrm{HCC}$ were received for management at Tanta University Hospitals, within the last 3 years (from March 2009 to February 2012) and twenty patients with cirrhosis, and without any evidence of HCC as control, with matched age, sex, and social factors.

\section{Study area}

(Gharbia Governorate): The residence area of patients is generally a rural area containing villages and districts; most people are working in agriculture, and the area is highly endemic with $\mathrm{HCV}$, and to a lesser extent HBV. This area has important chemical industrial factories in Kafr El-Zayat district, where unfortunately non-B non-C HCC patients were received.

\section{Methods}

All patients were subjected to: History taking included demographic variables, and environmental exposures. Clinical assessment and diagnosis of HCC was based on detection of hepatic focal lesions by imaging techniques (ultrasonography with, or without triphasic CT scans) plus serum alpha-fetoprotein (Sorin Biomedica - 3rd generation ELISA) and guided liver \& tumor biopsy for histopathological confirmation. Tumor staging was done according to Llovet, et al. (1999).

\section{Serological investigations for viral etiology}

Sera were tested for HCV antibody (Qualitest HCV-3rd generation ELISA) confirmed by RT-PCR using the automated Cobas Amplicor system of Roche. HBV infection was assessed using: $\mathrm{HBs} \mathrm{Ag}$ and $\mathrm{HBc} \mathrm{Ab}$ IgG (in negative $\mathrm{HBs} \mathrm{Ag}$ ) by $3^{\text {rd }}$ generation ELISA, and HBVDNA for patients with negative $\mathrm{HBs} \mathrm{Ag}$ and $\mathrm{HBc} \mathrm{Ab}$ IgG using the automated Cobas Amplicor system of Roche.

Serum total iron binding capacity, ceruloplasmin, and antinuclear antibody, were evaluated for the etiology of HCC patients.

Anti-p53 antibodies were evaluated by a modified ELISA test (Atta et al. 2008) to estimate the levels in sera of HCC patients and control groups, as a modification of Engvall and Perlmann (1971).

\section{The procedure in brief is as follows}

Polystyrene microtiter plates (Nunc Maxisorp, flat bottom) were coated with $100 \mu \mathrm{L}$ of recombinant wild-type human p53 protein (Sigma Chemical Company, USA) in the concentration of $5 \mu \mathrm{g} / \mathrm{mL}$ in Carbonate buffer, 0.06 $\mathrm{M}, \mathrm{pH}$ 9.6. The coated plate was incubated overnight at room temperature under humidified atmosphere. The plates were washed four times with phosphate buffered saline (PBS) containing $0.1 \%$ Tween 20 (PBS-T). The non-specific sites in the wells were blocked with $0.2 \%$ non-fat milk for 2 hours at $37^{\circ} \mathrm{C}$. After 4 washes with PBS-T, the plates were incubated with 1:1000 dilutions of the sera from patients and control groups. After 2 hours incubation at $37^{\circ} \mathrm{C}$ and washing, anti-human IgG whole molecule alkaline phosphatase conjugate (Sigma Chemical company, USA), at dilution 1:500 in PBS-T containing $0.2 \%$ non-fat milk, was added as the secondary antibody. At the end of 2 hours incubation at $37^{\circ} \mathrm{C}$ and washing, the color was developed by the addition of $100 \mu \mathrm{L}$ of the substrate, para-nitrophenyl phosphate (Sigma Chemical Company, USA) to each well. After arresting the reaction with $50 \mu \mathrm{L}$ of $3 \mathrm{~N} \mathrm{HCl}$, the optical density reading was taken in the microplate spectrophotometer (EL311 microplate autoreader, Bio-Tek instruments, USA) at $405 \mathrm{~nm}$ wave length. Cutoff level of ELISA above or below which the tested samples were considered positive or negative was calculated as the mean concentration using 0.04 OD cutoff points.

The study was approved by the Ethical and Research Committee of Tanta Faculty of Medicine and an informed consent was taken from each participant.

\section{Statistical analysis}

Was performed by the statistical software SPSS 11 using independent-sample $t$ test. Chi-square was applied for the results. $\mathrm{P}<0.05$ was considered statistically significant, and $<0.001$ highly significant. Analysis of variance [ANOVA] tests by SPSS V.16. Linear Correlation Coefficient $[\mathrm{r}]$ of the results was carried out.

\section{Results}

Serum total iron binding capacity, ceruloplasmin, and antinuclear antibody were detected in average values in non-B non-C HCC patients.

Table 1 showed: Non-B non-C ratio in HCC patients were $39 / 281=13.87 \%$, HCV were $186 / 281=66.19 \%$, HBV were $26 / 281=9.25 \%$ and $\mathrm{HCV} / \mathrm{HBV}$ co-infection $29 / 281=10.32 \%$. There is a rising incidence per year without significant difference $\mathrm{P}>0.05$.

Table 2 showed: The frequency of anti-p53 antibodies using a cutoff point of 0.4 OD in viral-associated HCC patients, were positive in 168 of 242 (69.42\%), non-B non-C HCC in 26 of $39(66.66 \%)$ and liver cirrhosis in 4 of 20 patients (20\%). No significant difference was detected between all groups as regard to age, and six ( $p>0.05)$. Serum level of P53 antibodies in non-B non-C HCC patients showed insignificant difference $(\mathrm{p}>0.05)$ as compared to viral-associated HCC, while significant as compared to cirrhosis. They had significant decrease in serum alpha-fetoprotein level $(\mathrm{p}<0.001)$ as compared to viral-associated HCC. Their tumors were mainly solitary and have smaller-sizes. 
Table 1 Number of viral and non-viral HCC patients and ratios/ year

\begin{tabular}{llll}
\hline Number in Years & Viral (HCV, HBV and co-infect.) & Non-B non-C & Total \\
\hline - First year & 74 (C: 57, B: 10, C\&B: 7) $=30.58 \%$ & $5=12.82 \%$ & $79=28.11 \%$ \\
- Second year & 83 (C: 62, B: 10, C\&B:11) $=34.30 \%$ & $10=25.64 \%$ & $93=33.10 \%$ \\
- Third year & 85 (C: 67, B: 6, C\&B:12) $=35.12 \%$ & $24=61.54 \%$ & $109=37.79 \%$ \\
Total in 3 years & 242 (C: 186, B: 26, C\&B:30) $=100 \%$ & $39=100 \%$ & $281=100 \%$ \\
\hline
\end{tabular}

There is insignificant increase in number of total HCC, viral, non-viral HCC patients when comparing between first, second and third year (P-Value $>0.05)$.

\section{Severity of liver disease}

\section{Child-Pugh score}

- Class A $\left(X^{2} 1=11.69, X^{2} 2=1.45, X^{2} 3=9.15\right)$. There was a significant increase in non-B non-C HCC group when compared to viral group.

- Class B $\left(X^{2} 1=0.22, X^{2} 2=2.56, X^{2} 3=0.95\right)$

- Class $C\left(X^{2} 1=13.8, X^{2} 2=0.033, X^{2} 3=6.12\right)$. There was a significant increase in viral group when compared to non-B non-C group.
Table 3: showed: Sensitivity, specificity, PPV, NPV and accuracy test of anti P53 antibody positive patients were $91.52 \%, 84.63 \%, 90.34 \%, 80.2 \%$ and $74.8 \%$ respectively.

Table 4: showed significantly positive correlations of P53 antibody with AFP, tumor size, tumor number, MELD score, Child-Pugh score, and Tumor staging.

Figure 1: showed CT scan with HCC in both lobes of liver of variant size while Figures 2 and 3 showed positive correlations of P-53 antibody with alpha fetoprotein

Table 2 Liver grading, tumors features, AFP and anti P53 findings in patient groups

\begin{tabular}{|c|c|c|c|c|c|c|}
\hline Items & Viral $(n=242)$ & Non-B nonC $(n=39)$ & Cirrhosis $(n=20)$ & $\mathrm{P} 1$ & P2 & P3 \\
\hline Age (years) & $51.9 \pm 11.7$ & $55.5 \pm 6.2$ & $53.1 \pm 95$ & $>0.05$ & $>0.05$ & $>0.05$ \\
\hline \multicolumn{7}{|l|}{ Gender: } \\
\hline - Male & $185(76.45 \%)$ & $37(94.87 \%)$ & $15(75.00 \%)$ & $>0.05$ & $>0.05$ & $>0.05$ \\
\hline - Female & $57(23.55 \%)$ & $2(05.13 \%)$ & $4(20.00 \%)$ & $>0.05$ & $>0.05$ & $>0.05$ \\
\hline \multicolumn{7}{|c|}{ Severity of liver disease: Child-Pugh score } \\
\hline - Class A & $80(33.06 \%)$ & $24(61.54 \%)$ & $4(20.00 \%)$ & $<0.05^{*}$ & $>0.05$ & $>0.05$ \\
\hline - Class B & $48(19.83 \%)$ & $9(23.08 \%)$ & $7(35.00 \%)$ & $>0.05$ & $>0.05$ & $>0.05$ \\
\hline - Class C & $114(47.11 \%)$ & $6(15.38 \%)$ & $9(45.00 \%)$ & $<0.05^{*}$ & $>0.05$ & $>0.05$ \\
\hline \multicolumn{7}{|l|}{ (MELD score) } \\
\hline - Early (6-11) & $48(19.83 \%)$ & $23(58.97 \%)$ & $3(15.00 \%)$ & $<0.001^{*}$ & $>0.05$ & $<0.05^{*}$ \\
\hline - Intermed.(12-18) & $84(34.71 \%)$ & $10(25.64 \%)$ & $8(40.00 \%)$ & $>0.05$ & $>0.05$ & $>0.05$ \\
\hline - Sever (19-40) & $110(45.45 \%)$ & $6(15.38 \%)$ & $9(55.00 \%)$ & $<0.05^{*}$ & $>0.05$ & $>0.05$ \\
\hline Anti P53 antibody + ve & $168(69.42 \%)$ & $26(66.66 \%)$ & $4(20.00 \%)$ & $>0.05$ & $<0.05^{*}$ & $<0.05^{*}$ \\
\hline \multicolumn{7}{|l|}{ AFP (ng/mL) } \\
\hline$-<200$ & $52(21.48 \%)$ & $31(79.49 \%)$ & $20(100 \%)$ & $<0.001^{*}$ & $<0.001^{*}$ & $>0.05$ \\
\hline$-200-500$ & $84(34.71 \%)$ & $5(12.82 \%)$ & - & $>0.05$ & $<0.05^{*}$ & $>0.05$ \\
\hline$->500$ & $106(43.80 \%)$ & $3(07.69 \%)$ & - & $<0.05^{*}$ & $<0.05^{*}$ & $>0.05$ \\
\hline \multicolumn{7}{|l|}{ Tumor findings US/CT } \\
\hline \multicolumn{7}{|l|}{ Size $(\mathrm{cm}):$} \\
\hline$<3$ & $44(18.18 \%)$ & $26(66.66 \%)$ & - & $<0.001^{*}$ & - & - \\
\hline $3-5$ & $98(40.50 \%)$ & $9(23.08 \%)$ & - & $>0.05$ & - & - \\
\hline$>5$ & $100(41.32 \%)$ & $4(10.26 \%)$ & - & $<0.05^{*}$ & - & - \\
\hline \multicolumn{7}{|l|}{ Number of tumors: } \\
\hline Single & $148(61.16 \%)$ & $33(84.62 \%)$ & - & $>0.05$ & - & - \\
\hline Multiple & $94(38.84 \%)$ & $6(15.38 \%)$ & - & $>0.05$ & - & - \\
\hline
\end{tabular}

Significant ${ }^{*} P$ value $<0.05$ Highly Significant * $P$ value $<0.001$.

$\mathrm{P} 1=$ viral vs. non-viral group P2 = viral vs. cirrhosis group.

$\mathrm{P} 3=$ non-viral vs. cirrhosis group. 
Table 3 Sensitivity, Specificity, PPV, NPV and Accuracy test of anti P53 antibody + ve patients

\begin{tabular}{cc}
\hline & Anti P53 antibody + ve \\
\hline Sensitivity & $91.52 \%$ \\
Specificity & $84.63 \%$ \\
PPV & $90.34 \%$ \\
NPV & $80.2 \%$ \\
Accuracy & $74.8 \%$ \\
\hline
\end{tabular}

in non-B non-C HCC group and P53 antibody with tumor size in non- $\mathrm{B}$ non- $\mathrm{C} \mathrm{HCC}$ respectively.

\section{Discussion}

Chronic $\mathrm{HBV}$, and $\mathrm{HCV}$, are the most important risk factors in the development of HCC (Tornai 2010) in agreement with the present results. Egypt has the highest prevalence of $\mathrm{HCV}$ worldwide, and has rising rates of HCC (Lehman and Wilson 2009). Prevalence of $\mathrm{HBV}$, and $\mathrm{HCV}$ were reported $25.9 \%$, and $78.5 \%$ among HCC cases respectively (Severi et al. 2010).

$\mathrm{HCC}$ in previous studies confirmed wide international variation risks (Franceschi and Raza 2009). Multiple non-viral factors have been implicated in the development of HCC (Soliman et al. 2010). Approximately, 10\% of HCC patients were reported negative for both HBV markers and antibodies to HCV (Kusakabe et al. 2007). In the current work, a higher rate $13.87 \%$ of non- $\mathrm{B}$ non$\mathrm{C}$ was detected, while Abe et al. (2008) reported increasing ratio from $17.8 \%$ in 2000 to $28.6 \%$ in 2006 in Japan. This difference in prevalence, between Egypt, and Japan could be attributed to the difference in environmental risks, and the higher prevalence of HCV in Egypt.

In the current study, no significant difference was detected between non-B non-C HCC, and those of viralassociation, as regard to age, or gender in agreement with previous reports (Asahina et al. 2010, and Yeh and Chen 2010). Some difference could be attributed to the nature of work making men more exposed to more risks, and/or the intensity of these risks.

Table 4 Correlations of P-53 antibody with AFP, tumor size, tumor number, MELD score, Child-Pugh score, and Tumor staging

\begin{tabular}{cccccc}
\hline P-53 antibody & \multicolumn{2}{c}{ Non-B non-C } & & \multicolumn{2}{c}{ Viral-associated } \\
\cline { 2 - 3 } \cline { 6 - 6 } & r. & p. value & & r. & p. value \\
\hline AFP (ng/mL) & 0.704 & 0.001 & & 0.880 & 0.001 \\
Tumor Size (cm) & 0.829 & 0.001 & & 0.896 & 0.001 \\
Tumor Number & 0.573 & 0.001 & & 0.815 & 0.001 \\
MELD score & 0.790 & 0.001 & & 0.848 & 0.001 \\
Child-Pugh score & 0.764 & 0.001 & & 0.810 & 0.001 \\
Tumor stage & 0.856 & 0.01 & & 0.472 & 0.003 \\
\hline
\end{tabular}

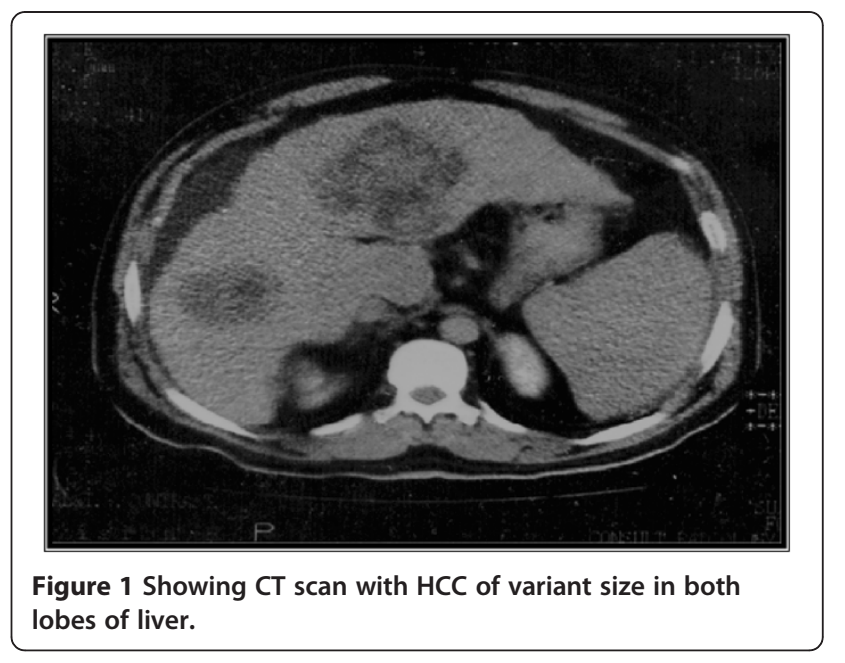

According to our knowledge, there are no previous reports for non-B non-C $\mathrm{HCC}$ in our region, but reports of exposure to chemicals in $\mathrm{HCV}$-associated $\mathrm{HCC}$ were reported. Chemicals can induce hepatic carcinogenesis through direct hepatotoxicity, inducing oxidative stress, and/or causing steatohepatitis (Angulo 2002), which seems to have a cumulative effect.

In our study, serum total iron binding capacity, ceruloplasmin, and antinuclear antibody were detected in average values in non-B non-C HCC patients. This could exclude the role of iron, copper and auto immunity in hepatic carcinogenesis of this group.

In the current study, anti-p53 showed insignificant difference between both HCC groups of patients, suggesting the presence of non-viral onchogens in non$\mathrm{B}$ non-C HCC patients. This could agree with previous results, with high percentage of positivity of anti-p53 antibodies in Egyptian healthy subjects (Attallah et al. 2009, and Gadelhak et al. 2009). They mentioned that

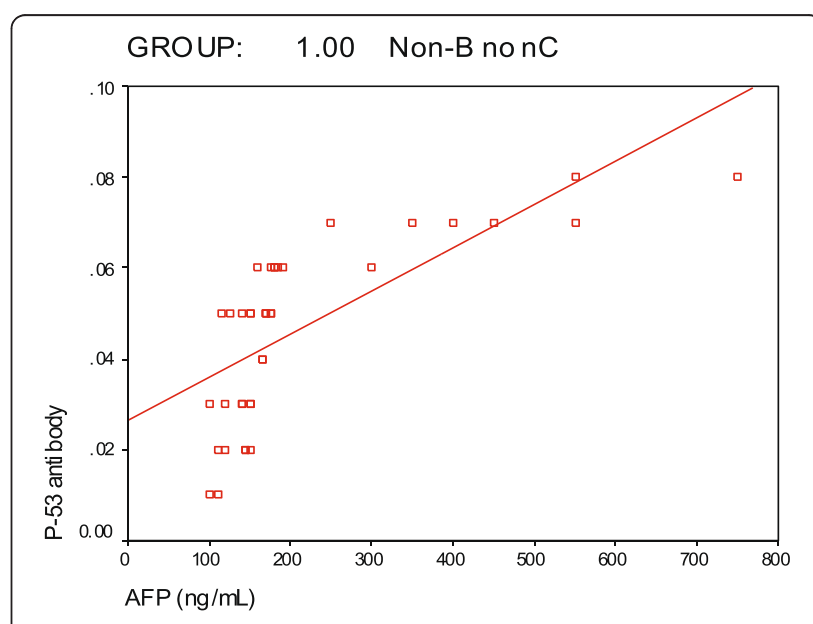

Figure 2 Correlation of P-53 antibody with alpha fetoprotein in non-B non-C HCC group. 


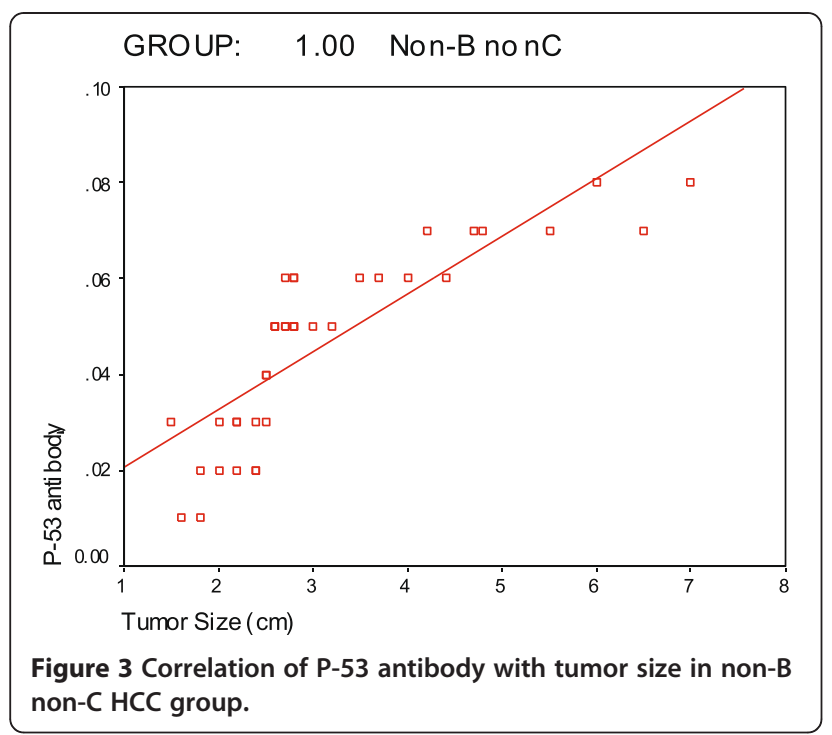

tumor suppressor genes may play a role in the puzzle of hepatic carcinogenesis. The finding of P53 antibodies in sera of individuals who are at high risk of cancer, as workers exposed to chemicals indicates that they have onchogenic potential, and promising in the early detection of cancer. Expressions were more pronounced in patients with HCC more than patients with liver cirrhosis, which could be of clinical importance for early diagnosis. This could be explained by interactions of chemical carcinogens, and genetic variations, are possible in HCC (Zhang 2010).

Alpha fetoprotein showed significantly lower levels in non-B non-C HCC, as compared to patients with viralassociated $\mathrm{HCC}$ in agreement with a previous report (Yamagishi et al. 2004), as tumors were detected of almost solitary, and of small sizes. High ratios of sensitivity, specificity, PPV, NPV and accuracy test of anti P53 antibody positive patients which could suggest clinical significance in non-B non-C HCC patients.

\section{Conclusion}

The study revealed that HCC increasing rate is not only due to high endemicity of HCV and/or HBV but also due to non- $B$ non- $C$ environmental risks. Low serum alpha-fetoprotein level in non-B non-C HCC may add a difficulty in screening of these patients. The high prevalence of serum anti-p53 in our study could suggest evidence of high onchogenicity and could be of help in diagnosis and intervention in presence of low levels of alpha-fetoprotein.

\section{Competing interest}

The authors declare that they have no competing interest.

\section{Authors' contributions}

AEA A: provided the research idea, designed the work, shared evaluation of the patients, draft the manuscript and final approval of the version. YM: shared evaluation of patients, biopsy taking, collect data and statistical analysis. SR : shared evaluation of patients, sampling, collect data and helped to draft the manuscript. MW : shared evaluation of patients, sampling, collect data and helped to draft the manuscript. TS : collect data, shared in statistical analysis and helped to draft the manuscript. GH: Histopathologial studies. MN: laboratory investigations. All authors read and approved the final manuscript.

\section{Acknowledgement}

We are grateful to members of The Egyptian Society of Liver and Environment for their partial support.

\section{Author details}

${ }^{1}$ Faculty of Medicine, Tanta University, Egypt and president of the Egyptian Society of Liver and Environment, Tanta, Egypt. ${ }^{2}$ Faculty of Medicine, Tanta University, Tanta, Egypt. ${ }^{3}$ National research Institute, Cairo, Egypt.

Received: 24 September 2012 Accepted: 4 February 2013 Published: 25 February 2013

\section{References}

Abdel-Hamid NM (2009) Recent insights on risk factors of hepatocellular carcinoma. World J Hepatol 31;1(1):3-7

Abe H, Yoshizawa K, Kitahara T, Aizawa R, Matsuoka M, Aizawa Y (2008) Etiology Etiology of non-B non-C hepatocellular carcinoma in the eastern district of Tokyo. J Gastroenterol 43(12):967-974

Angulo P (2002) Nonalcoholic fatty liver disease. N Engl J Med 346:1221-1231

Anwar WA, Khaled HM, Amra HA, El-Nezami H, Loffredo CA (2008) Changing pattern of hepatocellular carcinoma (HCC) and its risk factors in Egypt: possibilities for prevention. Mutat Res 659(1-2):176-184

Asahina Y, Tsuchiya K, Tamaki N, Hirayama I, Tanaka T, Sato M, Yasui Y, Hosokawa T, Ueda K, Kuzuya T, Nakanishi H, Itakura J, Takahashi Y, Kurosaki M, Enomoto $\mathrm{N}$, Izumi N (2010) Effect of aging on risk for hepatocellular carcinoma in chronic hepatitis C virus infection. Hepatology 52(2):518-527

Atta MM, El-Masry SA, Abdel-Hameed M, Baiomy HA, Ramadan NE (2008) Value of serum anti-p53 antibodies as a prognostic factor in Egyptian patients with hepatocellular carcinoma. Clin Biochem 41(14-15):1131-1139

Attallah AM, Shiha GE, Ismail H, Mansy SE, El-Sherbiny R, El-Dosoky I (2009) Expression of p53 protein in liver and sera of patients with liver fibrosis, liver cirrhosis or hepatocellular carcinoma associated with chronic HCV infection. ClinBiochem 42(6):455-461

Di Cesare E, Previti M, Lombardo F, Di Benedetto A, Mazzù N, Romano G, De Luca F, Lasco A, Cucinotta D (2001) Serum anti-p53 antibodies inpatients with type 1 diabetes. Ann Clin Lab Sci 31:253-258

Engvall E, Perlmann P (1971) Enzyme Linked Immunosorbent Assay (ELISA): quantitative assay of IgG. Immunochemistry 8:871-878

Ertle J, Dechêne A, Sowa JP, Penndorf V, Herzer K, Kaiser G, Schlaak JF, Gerken G, Syn WK, Canbay A (2010) Nonalcoholic fatty liver disease progresses to HCC in the absence of apparent cirrhosis. Int J Cancer, Epub ahead of print

Franceschi S, Raza SA (2009) Epidemiology and prevention of hepatocellular carcinoma. Cancer Lett 286(1):5-8

Gadelhak NA, Gadelhak SA, El-Morsi DA, Abdelaziz MM, Abbas AT, El-Emshaty HM (2009) Prognostic significance of three hepatitis markers (p53 antibodies, vascular endothelial growth factors and alpha fetoprotein) in patients with hepatocellular carcinoma. Hepatogastroenterology 56(94-95):1417-24

Kusakabe A, Tanaka Y, Orito E, Sugauchi F, Kurbanov F, Sakamoto T, Shinkai N, Hirashima N, Hasegawa I, Ohno T, Ueda R, Mizokami M (2007) A weak association between occult HBV infection and non-B non-C hepatocellular carcinoma in Japan. J Gastroenterol 42(4):298-305

Lehman EM, Wilson ML (2009) Epidemiology of hepatitis viruses among hepatocellular carcinoma cases and healthy people in Egypt: a systematic review and meta-analysis. Int J Cancer 124(3):690-7

Lehman EM, Soliman AS, Ismail K, Hablas A, Seifeldin IA, Ramadan M, El-Hamzawy H, Shoushtari CS, Wilson ML (2007) Patterns of hepatocellular carcinoma incidence in Egypt from a population-based cancer registry. Hepatol Res 38 (5):465-73

Llovet JM, Bru C, Bruix J (1999) Prognosis of hepatocellular carcinoma: The BCLC staging classification. Semin Liver Dis 19:329-338 

(2001) p53 codon 249 mutation in hepatocellular carcinomas from Nigeria. Afr J Med Sci 30:125-7

Severi T, vanMalenstein H, Verslype C, van Pelt JF (2010) Tumor initiation and progression in hepatocellular carcinoma: risk factors, classification, and therapeutic targets. Acta Pharmacol Sin 31(11):1409-20

Shimada H, Ochiai T, Nomura F (2003) Titration of serum p53 antibodies in 1,085 patients with various types of malignant tumors: a multiinstitutional analysis by the Japan p53 Antibody Research Group. Cancer 97:682-689

Soliman AS, Hung CW, Tsodikov A, Seifeldin IA, Ramadan M, Al-Gamal D, Schiefelbein EL, Thummalapally P, Dey S, Ismail K (2010) Epidemiologic risk factors of hepatocellular carcinoma in a rural region of Egypt. Hepatol Int 4 (4):681-90

Soussi T (2000) p53 Antibodies in the sera of patients with various types of cancer: a review. Cancer Res 60(7):1777-88

Tornai I (2010) Role of environmental factors in the etiology of hepatocellular carcinoma. Orv Hetil 151(28):1132-6

Wang XW, Hussain SP, Huo TI, Wu CG, Forgues M, Hofseth $L$, Brechot C, Harris CC (2002) Molecular pathogenesis of human hepatocellular carcinoma. Toxicology 181-182:43-47

Yamagishi Y, Horie Y, Kajihara M, Konishi M, Ebinuma H, Saito H, Kato S, Yokoyama A, Maruyama (2004) Hepatocellular carcinoma in heavy drinkers with negative markers for viral hepatitis. Hepatol Res 28(4):177-183

Yeh SH, Chen PJ (2010) Gender disparity of hepatocellular carcinoma: the roles of sex hormones. Oncology 78(Suppl 1):172-9

Zhang YJ (2010) Interactions of chemical carcinogens and genetic variation in hepatocellular carcinoma. World J Hepatol 27(2(3)):94-102

doi:10.1186/2193-1801-2-69

Cite this article as: Abou El Azm et al: Serum anti-P53 antibodies and alpha-fetoprotein in patients with non-B non-C hepatocellular carcinoma. SpringerPlus 2013 2:69.

\section{Submit your manuscript to a SpringerOpen ${ }^{\circ}$ journal and benefit from:}

- Convenient online submission

- Rigorous peer review

- Immediate publication on acceptance

- Open access: articles freely available online

- High visibility within the field

- Retaining the copyright to your article

Submit your next manuscript at $>$ springeropen.com 